\title{
Refuge
}

Canada's Journal on Refugees

Revue canadienne sur les réfugiés

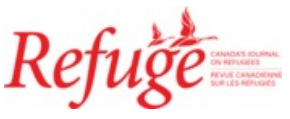

\section{Accommodating Asylum Seekers and Refugees in Indonesia: From Immigration Detention to Containment in "Alternatives to Detention"}

\section{Antje Missbach}

Volume 33, Number 2, 2017

URI: https://id.erudit.org/iderudit/1043061ar

DOI: https://doi.org/10.7202/1043061ar

See table of contents

Publisher(s)

Centre for Refugee Studies, York University

ISSN

0229-5113 (print)

1920-7336 (digital)

Explore this journal

Cite this article

Missbach, A. (2017). Accommodating Asylum Seekers and Refugees in Indonesia: From Immigration Detention to Containment in "Alternatives to Detention”. Refuge, 33(2), 32-44. https://doi.org/10.7202/1043061ar

\section{Article abstract}

Considered the last 'stepping stone' before Australia, Indonesia plays an important role in immobilising secondary movements of asylum seekers and refugees in Southeast Asia. While migration scholarship has dedicated substantial attention to immigration detention and the deplorable living conditions inside immigration detention centres (IDCs), this article explores "alternatives to detention" (ATD) in two Indonesian localities: the city of Makassar and the province of Aceh. Seeking to contribute to a critical examination of ATD more generally, this article examines individual freedom, mobility, mechanisms of care and aid provision, protection of rights, self-determination, and matters of personal safety. The article illustrates the remaining limitations and the lack of rights that asylum seekers and refugees in Indonesia continue to face outside of IDCs. A durable solution, in the form of integration, is not available to asylum seekers and refugees, as they are prevented from integrating into the local host societies, and their social and economic mobility remains widely restricted. Yet at the same time, despite more physical mobility in ATD, asylum seekers and refugees remain contained within Indonesia as their onward movement remains deterred as well.
Copyright (c) Refuge: Canada's Journal on Refugees, 2017

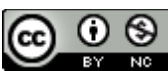

This document is protected by copyright law. Use of the services of Érudit (including reproduction) is subject to its terms and conditions, which can be viewed online.

https://apropos.erudit.org/en/users/policy-on-use/ 


\title{
Accommodating Asylum Seekers and Refugees in Indonesia: From Immigration Detention to Containment in "Alternatives to Detention"
}

\author{
ANTJE MISSBACH
}

\section{Abstract}

Considered the last 'stepping stone' before Australia, Indonesia plays an important role in immobilising secondary movements of asylum seekers and refugees in Southeast Asia. While migration scholarship has dedicated substantial attention to immigration detention and the deplorable living conditions inside immigration detention centres (IDCS), this article explores "alternatives to detention" (ATD) in two Indonesian localities: the city of Makassar and the province of Aceh. Seeking to contribute to a critical examination of ATD more generally, this article examines individual freedom, mobility, mechanisms of care and aid provision, protection of rights, self-determination, and matters of personal safety. The article illustrates the remaining limitations and the lack of rights that asylum seekers and refugees in Indonesia continue to face outside of IDCs. A durable solution, in the form of integration, is not available to asylum seekers and refugees, as they are prevented from integrating into the local host societies, and their social and economic mobility remains widely restricted. Yet at the same time, despite more physical mobility in ATD, asylum seekers and refugees remain contained within Indonesia as their onward movement remains deterred as well.

\section{Résumé}

Considérée comme le dernier tremplin vers l'Australie, l'Indonésie joue un rôle important pour bloquer les mouvements secondaires des demandeurs d'asile et des réfugiés en Asie du Sud-Est. Tandis que les études sur la migration se sont beaucoup focalisées sur la la détention des immigrants et les conditions de vie déplorables dans les les centres de détention des immigrants (CDI), cet article explore des alternatives à la détention $(A D)$ à deux endroits d'Indonésie: la ville de Makassar et la province d'Aceh. À des fins plus générales de contribution critique sur les CDI, il étudie la liberté individuelle, la mobilité, les mécanismes de soins et les dispositions d'aides, la protection des droits, l'autodétermination, et les questions de sécurité personnelle. Il illustre enfin les limites persistantes et le manque de droits auxquels font toujours face, en Indonésie, les demandeurs d'asile et les réfugiés à l'extérieur des CDI. Du fait qu'on les empêche de s'intégrer aux sociétés hôtes locales et que leur mobilité sociale et économique est extrêmement limitée, on ne leur offre pas de solution durable sous la forme d'une intégration. En dépit d'une certaine mobilité physique dans le cadre des $A D$, les demandeurs d'asile et les réfugiés restent confinés à l'intérieur de l'Indonésie du fait qu’on les décourage également d'aller de l'avant.

\section{Introduction}

In June 2013, Human Rights Watch published a damning report entitled Barely Surviving: Detention, Abuse, and Neglect of Migrant Children in Indonesia, which highlighted the situation of hundreds of incarcerated minor asylum seekers and refugees in immigration detention centres 
(IDCS); it also provided insights into the more general situation of almost 13,000 adult asylum seekers and refugees in Indonesia at the time. ${ }^{1}$ Primary responsibility for the lack of protection, maltreatment, and abuse in detention was attributed to the Indonesian government, ${ }^{2}$ but Human Rights Watch attributed secondary responsibility to the Australian government, which had long provided substantial funding to the Indonesian immigration detention system in order to deter the irregular onward movement of those immobilized people to Australia. ${ }^{3}$ Exactly one year later, the Office of the United Nations High Commissioner for Refugees (UNHCR) introduced a new global strategy, "Beyond Detention 20142019," to help governments cease detaining asylum seekers and refugees. The three main goals agreed under this strategy are "(1) to end the detention of children; (2) to ensure that alternatives to detention (ATD) are available in law and implemented in practice; and (3) to improve conditions of detention, where detention is necessary and unavoidable, to meet international standards." 4 To assist Indonesia implement the strategy, a National Action Plan was drawn up with relevant Indonesian ministries, the UNHCR office in Jakarta and its local implementing partners, the International Organization for Migration (IOM), and the Indonesian Human Rights Commission (комNAS нам). ${ }^{5}$

In light of growing recognition of detention's harm to detainees as well as its high financial costs, governments around the world are exploring more cost-effective and humane options for accommodating immobilized asylum seekers and refugees. ${ }^{6}$ ATD rose to greater international attention with the launch of UNHCR's "Beyond Detention" strategy in 2015. An outcome of intense lobbying by NGOs, such as the International Detention Coalition (a global network of more than 300 NGOs) and Asia Pacific Refugee Rights Network (APPRN), the strategy picks up the call for accommodating asylum seekers in residential housing, open transit facilities, and shelters in local communities while their immigration statuses are being processed.7 Indonesian NGOs are involved in these NGO networks, but they were not the driving forces behind the campaigns.

There is no single legal definition of what determines ATD. While some scholars understand ATD to be a range of policies and practices employed by sovereign states to better manage immigration falling short of incarceration, ${ }^{8}$ Sampson et al. have suggested a number of minimum standards, including respect for fundamental rights, meeting basic needs, legal status and documentation, legal advice and interpretation, fair and timely case resolution, and regular review of placement decisions, which must be met in order qualify as ATD. 9 This article presents ATD as the physical and spatial lodging of asylum seekers and refugees outside prison-like IDCs. Although seen as improvements over closed institutions,
ATD also need further review before wide-scale adoption; however, the little critical research into ATD that has been conducted thus far has been confined to countries of the Global North. ${ }^{10}$

Three years after the launch of the "Beyond Detention" strategy, the article explores living conditions in Indonesian ATD in order to document what the gradual shift from IDCs to ATD has brought for those affected by it. While recent migration scholarship has produced a large critical body of literature on detention, ${ }^{11}$ with considerable attention also dedicated to Indonesian IDCs, ${ }^{12}$ this article questions their "alternative" dimension based on my encounters with a specific empirical reality in the field. This shift of attention from IDCs to ATDis significant in light of the shifting ratio of detained and undetained asylum seekers and refugees in Indonesia. ${ }^{13}$

The main argument put forward here is that ATD in Indonesia can be conceptualized as another form of containment, albeit with greater mobility. From this perspective, ATD mask a larger problem, one that might even be more complex than the release from IDCs, which is the lack of local integration for the asylum seekers and refugees currently in Indonesia. Local integration constitutes a durable solution, next to resettlement or voluntary repatriation. In analyzing my findings I have opted to apply the concept of carceral mobility, which I borrow from Moran, Piacentini, and Pallot. ${ }^{14}$ Moran, Piacentini, and Pallot provide a useful starting point through challenging the widespread assumption of "mobility as an expression of power," and that "mobility is connected with autonomy ... and, ultimately, 'freedom."'15 Their study on contemporary prisoner transport in the Russian Federation highlights in particular the punitive control and the carceral practices inherent in (coerced) mobility of prisoners.

Seeking to further explore carceral aspects of mobility, I pay attention to asylum seekers' and refugees' limited attainment of legal rights as well as their insufficient economic and social integration that, if it was granted, would allow for a standard of living similar to that of the local population and wider social and cultural acceptance. I demonstrate that despite greater physical mobility, asylum seekers and refugees in ATD lack the freedom to live a self-determined life because there is an absence of crucial rights that could otherwise enhance their economic and social mobility. On the basis of my analysis, the carceral mobility is characterized by an absence of rights insofar as those residing in ATD are prohibited from taking up work and have difficulty accessing education, therefore fostering dependency on aid and services. Despite high levels of control and surveillance, in the form of curfews, limited visiting rights, restricted radius of mobility, and regular police checks, I found a lack of physical safety for the ATD residents, as they fear attacks 
and encroachments by locals. ATD sustain zones of containment with semi-permeable boundaries that on the one hand provide little safety to asylum seekers and refugees, but on the other hand prevent meaningful integration.

In writing this article I pursue four goals. First, the empirical insights into temporary accommodation outside IDCs help produce a more holistic picture of the day-to-day reality faced by asylum seekers and refugees stuck in Indonesia. ${ }^{16}$ Second, I contribute to the overall debate on ATD beyond the Indonesian context, particularly in regard to individual freedom, mobility, the mechanisms of care, rights, and protection, and issues of personal safety, health, and well-being of asylum seekers and refugees in protracted transit situations. Third, I document the persistent indecision of the Indonesian government on its approach to detention and ATD. I argue that the Indonesian government has repeatedly opted for inconsistent and ad hoc approaches: it vacillates amongst a permissive laissez-faire attitude that allowed thousands of asylum seekers to pass through Indonesia freely; a hasty and heavy-handed use of incarceration in an overcrowded IDC system in keeping with the interests of Australian government funders, and a pragmatic shift to ATD. Fourth, I explore issues of personal safety and well-being of asylum seekers in Indonesian ATD and their effect on desired onward journeys. Here I argue that while the shift from IDCs to ATD is deemed more humane, it sustains the prevention of onward movement while mitigating against effective and long-term integration of asylum seekers and refugees into Indonesian society.

This article is informed by long-term fieldwork in Indonesia between 2010 and 2016, a period that saw abrupt changes and gradual shifts in the Indonesian asylum-seeker regime. During many short trips (usually one month long) and a longer stint (eight months), I have (re)visited six IDCs (Kalideres, Pontianak, Tanjung Pinang, Kupang, Semarang, and Makassar), four refugee camps (Aceh), three NGO shelters for underage asylum-seekers, a private and a state-owned orphanage (both in Jakarta), more than a dozen community shelters (Makassar, Medan, Yogyakarta, and Jakarta), and many self-funded lodgings, such as shared apartments and doss-houses (Jakarta and Puncak). ${ }^{17}$ As there is no coherent policy for accommodating transiting asylum seekers and refugees in Indonesia, it was important to gain an overview of the variety of housing options, in regard to configuration, capacity, regulations or provisions. With no "typical" ATD in place, I have decided to compare two sites: community shelters in Makassar and makeshift camps in Aceh. Given that asylum seekers and refugees based in Jakarta and Puncak have received the bulk of attention by scholars and journalists, it is important to provide some snapshots on residency areas usually considered peripheries within the Indonesian archipelago. While the first site is considered a "best practice example" by the Indonesian government and therefore gives an impression of ATD at their best, the other is an ad hoc example, so provides a useful comparison of how contingency affects ATD. Both sites depict difficulties relevant to other ATD. Only two cases can be examined (largely because of word limitations) to provide a more detailed sense of material conditions and everyday routines in those sites. The broader claims about ATD, however, draw on the wider ethnographic research within and amongst residents of the full suite of ATD operating in Indonesia.

The ATD in Makassar came into existence in 2011, when IOM started using two hotels for housing asylum seekers and refugees who could not be placed in the local IDC. From then on, the number of ATD grew steadily; in June 2013 there were already 10 ATD facilities in use and 12 in January 2015. ${ }^{18}$ In April 2016, 2,036 asylum seekers and refugees were living in Makassar, of which 1,165 were under IOM care. While most of them lived in one of the 14 ATD in the city and its outskirts, 196 under IOM care were still held in an IDC in Makassar. ${ }^{19}$ Unlike in other cities, no women and children were detained in the IDC in Makassar. ${ }^{20}$ In general, Makassar enjoyed a fairly high reputation amongst asylum seekers who decided to self-report to the migration authorities there, ${ }^{21}$ regardless of repeated public statements by the Makassar immigration authorities that they did not want to receive any more asylum seekers and refugees in either the IDC or the ATD. Despite these challenges, the ATD in Makassar is seen as a success by the central government, because in February 2016, the governor of South Sulawesi received an award from the Indonesian minister of law and human rights for superior efforts of the Makassar immigration authorities in "supervising foreigners." 22

The refugee camps in Aceh, in contrast, result from ad hoc emergency responses and were-as makeshift solutions-extended over time, making the camps in Aceh ATD by chance. Generally speaking, Indonesia had not seen any refugee camps since the Indochinese refugees were housed on the island of Galang in the late 1970s until the mid-199os, so the Aceh camps were a novelty. ${ }^{23}$ In May 2015, 1,807 asylum seekers of the persecuted Rohingya ethnic and religious minority from Myanmar became stranded in Aceh, Sumatra's northernmost province. ${ }^{24}$ There are no IDCs in Aceh to accommodate them, and IDCs in other provinces were already overcrowded. Even though in previous years other Rohingya had come to Indonesia and faced the usual detention procedures, this new group was handled differently. ${ }^{25}$ The Indonesian government issued an unprecedented ultimatum that it would tolerate the Rohingya's presence only on the condition that the UNHCR arrange resettlement or repatriation within one year. ${ }^{26}$ Since resettlement has been minimal so far, Indonesia has yet to find a solution 
for the remaining Rohingya beyond the one-year deadline that ended in May 2016. Local governments in Aceh were explicitly prohibited from using local budgets to cater for the Rohingya (apart from initial emergency efforts);27 however, the IOM and some 20 Indonesian NGOs were permitted to establish and administer camps for the Rohingya in Aceh. Conditions in the camps varied but were below the standards for sanitation, hygiene, and safety in other ATD. As the camps were intended for short-term use only, the building materials were generally of low quality. Compared to the community shelters in Makassar, which were deemed exemplary, the makeshift camps in Aceh ranked at the lower end of the ATD spectrum.

During fieldwork I spoke to more than 90 asylum seekers and refugees (mostly men) during their detention, but usually after their release from an IDC, and in some cases before their "voluntary" surrender to an IDC. The research was complemented by recurrent interviews with representatives from the UNHCR and IOM, Indonesian and non-Indonesians members of NGOs (e.g., SUAKA, Jesuit Refugee Service, Church World Service, Aksi Cepat Tanggap), and with many low- to mid-level Indonesian migration and police officers in charge of handling asylum seekers and refugees. I observed a number of focus group discussions and coordination meetings involving high-level representatives from the special ministerial task force for handling people smuggling, asylum seekers and refugees (Desk Penangan Penyelundupan Manusia, Pengungsi dan Pencari Suaka, P2MP2s). I formally interviewed representatives of central and local government on their tasks in handling asylum seekers and refugees. I conducted all interviews in Indonesian or English. Interpreters were not used at any point. I complement the observations from the field with Indonesian media reports, which are often overlooked in research that focuses on Indonesia.

\section{Asylum Seekers in Indonesia: From Transit to Protracted Stay}

Indonesia's growing interest in policing irregular migration is not mirrored by an interest in refugee protection. Indonesia remains reluctant to sign the 1951 Refugee Convention, largely because of the obligation entailed to provide for the permanent integration into Indonesia of recognized refugees. Defending this position, Indonesian government representatives often claim that Indonesia already complies "with the principle and spirit of the 1951 Convention." ${ }^{28}$ Although this claim is questionable, Indonesia has allowed the UNHCR to process asylum-seeker claims on its territory and the Iом to provide a wide range of services to asylum seekers and refugees. ${ }^{29}$

The asylum-seeker and refugee population in Indonesia is small, especially by comparison with that of with its neighbours. ${ }^{30}$ At the end of March 2016, 7,381 asylum seekers and 6,467 refugees were registered with the UNHCR in Jakarta. Of these 13,848 people, 10,253 were male and 3,595 were female; 3,552 were under 18 , including 643 unaccompanied or separated children..$^{31}$ UNHCR statistics reveal that almost a third of the current population of asylum seekers and refugees (4,270 persons, including 3,182 asylum seekers and 1,088 refugees, of whom 845 were female and 846 were children, with 138 being unaccompanied and separated children) were detained in IDCs and temporary quarantine facilities under immigration supervision. Indonesia has 13 permanent IDCs and 20 temporary detention facilities in 12 provinces, with a combined capacity for 3,000 people. Because of overcrowding in IDCs and unwillingness to build additional centres, Indonesia has opted for ATD. IOM statistics in April 2016 indicate that 4,132 asylum seekers and refugees (47 per cent of all those under its care) were hosted in ATD. In 2016, there were 42 community shelters and housing facilities located in six Indonesian provinces, often in or near the cities that have IDCs, such as Jakarta, Medan, Surabaya, and Makassar. Indonesian authorities estimated that in October 2015 at least 5,000 asylum seekers and refugees were renting private accommodation in Puncak and Jakarta. ${ }^{32}$ While precise numbers vary according to different agencies and authorities, most asylum seekers and refugees are now living outside IDCs, either in ATD or in independent accommodation.

The reasons many asylum seekers and refugees still remain in IDCS, despite the UNHCR's "Beyond Detention" strategy, are to be found not only in the insufficient numbers of ATD in Indonesia, but also in the large number of people who surrender themselves to IDCs. 33 Between 2014 and 2015, nearly 4,000 asylum seekers and refugees reported themselves to immigration authorities, seeking to be detained because they could no longer afford to support themselves independently outside the detention system. ${ }^{34}$ This development does not necessarily undermine the UNHCR "Beyond Detention" strategy; rather it is a perverse component of it. In order to be placed in an ATD, asylum seekers and refugees must be registered by Indonesian immigration authorities, and the most efficient way to register is to be placed in temporary immigration detention, as I explain later in more detail.

While between 2014 and 2016 fewer people arrived in Indonesia than in 2010-13, more and more asylum seekers and refugees are staying in Indonesia for longer periods of time. The reasons are twofold. First, opportunities for onward movement (refugee resettlement to third countries) have decreased since Australia cut its resettlement quota from Indonesia dramatically in November 2014, and no other potential resettlement countries have stepped in to compensate. Second, irregular onward migration to Australia also decreased after Australia adopted more restrictive 
policies in September 2013. ${ }^{35}$ Australia closed all options for asylum seekers arriving by boat to be processed in and resettled to Australia. In some cases, those asylum seekers are forcibly returned to Indonesia (or Vietnam and Sri Lanka in the case of nationals of those countries subjected to "enhanced screening" and found not to have valid protection claims). Others are directed to offshore detention centres in Nauru and Manus Island (Papua New Guinea). Although these policies deny asylum seekers access to Australia, they have not stemmed the flow of asylum seekers within the wider Asia-Pacific region. The many conflicts in Asia, North Africa, and the Middle East still force many people to leave their homelands in search of safer places to live. Persecuted and forcibly displaced people continue to arrive in countries such as Indonesia and Malaysia, many seeking transit to potential resettlement countries. As a result, Indonesia has become a reluctant host to asylum seekers and refugees whose "transit" through Indonesia is likely to entail a prolonged and potentially indefinite stay. ${ }^{36}$

In 2011, before the number of asylum seekers crossing from Indonesia to Australia peaked, Patrialis Akbar, Indonesian minister for law and human rights, stated that existing IDCs were sufficient to meet demand. ${ }^{37}$ At that time, a number of state-owned and state-operated IDCs around Indonesia (such as those in Tanjung Pinang and Semarang) had been refurbished and extended with the help of Australian funding. Even though the number of registered asylum seekers and refugees has increased since then, Indonesia has given no indication that it will build additional permanent IDCS, relying instead on temporary detention facilities and ATD. The reasons are complex, entailing, first of all, domestic administrative and fiscal hurdles for the establishment of new IDCs, as asylum seekers' issues are currently not a high priority issue and more importantly, Indonesian-Australian unsteady relations over security and migration issues. ${ }^{38}$ Extending IDC with or without Australian funding would be seen as too much a favour for Australia. However, Indonesia's reluctance to enlarge its IDC system predated the UNHCR's global "Beyond Detention" strategy. Out of pragmatic necessity, Indonesia had already made use of IOM-administered and Australian funded ATD for more than a decade. ${ }^{39}$ By its own account, "for the past 13 years, IOM Indonesia has been at the forefront in supporting the Indonesian Government's continuing efforts to promote alternatives to detention for refugees and smuggled migrants." 40 Although ATD emerged as a temporary "solution," they are increasingly becoming permanent sites of accommodation for asylum seekers and refugees awaiting resettlement.

One of the more perverse bureaucratic features of the ad hoc arrangements applying to asylum seekers and refugees is that the only pathway into an IOM-managed ATD is via temporary detention. Some Indonesian migration officials earn extra money from asylum seekers, by making them pay to be detained in (and released from) an IDC or simply stealing from their belongings. ${ }^{41}$ There is no official short-cut to direct placement in one of the IOM's community shelters or, in turn, to receipt of IOM "care" in those shelters, which may include for instance, limited cash payments, access to recreational activities and psycho-social treatments. Upon their release from an IDC, asylum seekers and refugees have no choice as to which ATD they are placed in. Also, they must sign a declaration of compliance, which includes restrictions on mobility and housing, prohibitions on visiting airport and seaports, biweekly reporting requirements, requests to comply with Indonesian law and display "cooperative behaviour in the neighbourhood." 42 Although at first glance these rules appear straightforward and reasonable, at least to those fluent in English, they leave open a number of questions, such as how big the specific designated area is or what "cooperative behaviour" means in practice. Leaving certain rules rather vague provides authorities with more discretionary power. High levels of discretion, if not arbitrary implementation of rules, by immigration officials and other authorities evoke hyper-cautiousness and sometimes fear among the ATD residents. Compliance with the many regulations is enhanced by the mere risk of readmission into an IDC. This prospect hangs over the ATD enrolees like the sword of Damocles, and therefore the carceral mobility, as manifested in ATD, is rooted in the punitive quality of the IDC.

While many ATD have been enlarged in the initial phase of the "Beyond Detention" strategy, the implementation of consistent regulations for ATD throughout the country is yet to be achieved, until which time claims of unfairness and arbitrariness will likely persist among asylum seekers and refugees. On the visits to several ATD facilities, I found that conditions and rules varied widely, as did levels of freedom enjoyed. For example, in some ATD residents received monthly cash stipends of us $\$ 100$, in others they did not. Those who did not receive cash to buy their own food were provided with catered meals, not very different from IDCs, which proved to be a source of ongoing frustration. Not only was the selection of those meals limited, but also the quality was poor. Without the right to decide for themselves what to eat and when over a protracted period of time, ATD residents are denied the very basic dignities of life and are subjected to other people's taste, routine, and priorities. Not only do food provisions cause another loss of control of one's life, but food provisions foster dependency. Therefore they are a tool for monitoring and disciplining ATD residents, as absentees are left out from the distribution and are eventually deregistered from the ATD. The synergies between providing food assistance and monitoring asylum seekers are well-known 
and also applied in other countries. ${ }^{43}$ I will now flesh out the living conditions in two ATD: the community shelters in Makassar and makeshift camps in Aceh.

\section{Makassar: IOM-Funded Community Housing}

While in Makassar in May 2015, I visited two centrally located ATD. The tall new buildings were distinct from other housing on the street. One building accommodated single males, and another was for families. In each case, either two single people or one family shared one room, but children over eight years old were supposed to have their own room. Each room consisted of two single beds or one double bed, a bathroom, and a small, carpeted, sitting area. Each room had air-conditioning, but no windows. Only some rooms had light through glass bricks. Power blackouts were frequent. One Indonesian security guard watched over the residents but did not object to my visit.

The rules for living in the facility were printed in English, Indonesian, Arabic, and Farsi, and pinned next to the main door.44 Among them, driving vehicles, leaving Makassar, and receiving guests in one's room is prohibited, a curfew is imposed, and political involvement is forbidden. Not only does the list indicate how subjective the rules can be, as "strict sanctions" are not spelled out, it also unveils the selectivity of the Indonesians, for example featuring heightened agitation about "sexual misconduct" and other moral evils, such as gambling and night clubbing. The juxtaposition of "mak[ing] a scene" and "to be involved in political activities," which could theoretically also cover protests against the UNHCR or the IOM, is comprehensible only when taking into account the common complaints from local host communities, which are usually coloured by moral panic and racist undertones. Although I could discover whether any ATD residents had been returned to the IDC in Makassar, the possibility was expressed in informal chats. Escapes from the ATD take place from time to time, but usually in small numbers. 45

The greatest challenges, according to ATD residents, are the daily boredom and the uncertainty of whether and when they will be resettled. Women talked about tensions between individuals and families, and between parents and their children resulting from their ongoing frustration. Fights broke out occasionally among ATD residents. ${ }^{46}$ To pass the time, some men played football in the park or went to a gym. Some had organized their own English lessons. In interviews I found that most ATD residents kept the time they spent outside the facilities to a minimum and tried to avoid contact with the local community. According to them, the locals, who are Sunni Muslims, did not like the fact that they are Shia. ATD residents were told to not practise their faith publicly. Many of them had heard about anti-Shia incidents elsewhere in Indonesia. ${ }^{47}$
In order to improve relations between the locals and the ATD residents and minimize tension, the local government in Makassar, in cooperation with the IOM and UNHCR, organized some information sessions (sosialisasi). $4^{8}$ While asylum seekers and refugees were told not to do "anything stupid, not to make noise in the streets at night and not to party when others are in the local mosque," members of the local community were reminded to not "allow their daughters to dress up and keep a close eye on them" to prevent intimate friendships (pacaran). 49 Furthermore, the local government initiated "cleaning Sundays," in which locals and ATD inhabitants came together to clean the streets and sewage canals in their neighbourhood, after which they were provided with snacks and drinks. Members of the local administration hoped such orchestrated encounters would promote better relations and mutual responsibility for the area. ${ }^{50}$ Although meant to be a win-win for locals and refugees, the ATD residents felt this activity was another imposition on their lives. In order to avoid suspicions of being lazy, ungrateful refugees and to be perceived as good, compliant refugees they had to do "voluntary" work, which was represented as a reciprocal exchange, but it was in fact free labour for the local government that did not incur any costs for hosting the asylum seekers and refugees. In the words of an ATD resident who participated in those "cleaning Sundays" semi-compliantly, "It's not the Indonesian community that is providing for us here, it's the UN and IOM; if I do something for the local community I expect something in return."51 Although the local initiators were enthusiastic about the outcomes of these "cleaning Sundays," they ceased soon after my departure.52

While IOM public relations materials emphasize the leisure and learning activities made available to ATD residents, 53 such activities are relatively modest, and daily life appeared dreary. So far, only 22 children were allowed to attend a primary school in Makassar. ${ }^{44}$ The residents in the Makassar ATD could not cook for themselves but received catered meals three times a day. When I visited I saw many Styrofoam food containers unopened in the garbage bins. The people in this ATD did not receive a cash allowance, relying instead on monthly deliveries of toiletries, tea, sugar, coffee, clothes, and so on. Most had no money for phone credit and internet access (crucial for staying in touch with families abroad), and resorted to selling some of their aid provisions to local Indonesians at less than market value.

\section{Makeshift Camps in Aceh}

I visited the four camps in Aceh twice, in November 2015 and in April 2016. By that time only 281 Rohingya, including 48 minors, remained there. 55 From the initial number of 1,807 Rohingya, the UNHCR deemed only some 1,00o people eligible for temporary protection in Aceh. By September 2015, 
at least 642 Bangladeshi nationals who had initially claimed they were Rohingya had been "voluntarily" repatriated to Bangladesh. ${ }^{56}$ While in November 2015 some Rohingya still lived in tents, by April 2016 everybody was housed in barracks, some of them now in fact empty. According to press reports, most Rohingya absconded from the camps in order to reach Malaysia. ${ }^{57}$ Despite the shrinking numbers of Rohingya in Aceh, a new, more robust camp was opened in Langsa in April 2016, with room for 1,500 people, exceeding the number of remaining Rohingya. ${ }^{58}$

The main service provider for the camps was the IOM, responsible for the supply of drinking water, sanitation, food, and health care.59 Unlike other ATD, the camps in Aceh saw a great involvement of NGOs. Even though most other asylum seekers and refugees in Indonesia (Afghans, Pakistanis, and Somalis) are Muslim too, the plight of the Rohingya spurred an unprecedented sense of Muslim solidarity amongst Indonesians. Many Indonesians gave their zakat (compulsory tax for Muslims) to Muslim NGos involved in helping the Rohingya. ${ }^{60}$ Individuals also donated food and clothes or became volunteers. Aid and services delivered by NGOS included literacy programs, religious instruction, and skills training. In the camp in North Aceh, residents were provided with daily meals cooked by the villagers specifically employed for this task. Out of frustration, residents resorted to cooking secretly on open fires inside the wooden barracks. In all camps, Rohingya sold their donated mattresses, milk powder, shampoo, or soap to raise funds. ${ }^{61}$

Local authorities in North Aceh complained about NGO interference that not only undermined security arrangements but also was in conflict with rights provision. ${ }^{62}$ For example, an NGO arranged marriages between the Rohingya, including of underage girls, as they considered it inappropriate for unmarried men and women to live in the same camp. ${ }^{63}$ In a stand-off between that NGO and the local government, the state-employed guards quit their services for a period of time, resulting in break-ins into the depots where IOM and UNHCR stored aid provisions, and Rohingya absconded at NIGHT. ${ }^{64}$ More severely, in September 2015, four women alleged being raped during their arrest by locals following their attempted escape. ${ }^{65}$ The news caused panic and 200 residents stormed out of the camp, although most returned later. ${ }^{66}$ Amnesty International reported abuse and intimidation by local security staff, lack of protection from smugglers, as well as theft and beating of Rohingya by local gangs entering the camps. ${ }^{67}$

Members of NGOs and the local and central government have recognized the risk of tension between the Rohingya in the camps and the surrounding local population. Acehnese villagers, many of them very poor and with limited understanding of how the asylum seekers are handled, saw Rohingya being provided with goods and services that they themselves often yearn for. ${ }^{68}$ To reduce resentment, a number of information sessions were conducted. For example, in radio programs locals could voice their complaints and receive proper information from a community councillor. ${ }^{69}$ In response to the extended stay of the remaining Rohingya in Aceh, local governments had to offer small compromises on basic education and work. In March 2016, six Rohingya children were granted access to the local primary school in Langsa. ${ }^{70}$ Some new approaches, including refugees and local residents jointly raising livestock, are beginning to be implemented in the camp in North Aceh; it is too early to comment on the success of those non-remunerated employment schemes.

\section{Released from IDC, but Still Contained}

Living in a community shelter in Makassar and even in a makeshift camp in Aceh offers better living conditions than in prison-like IDCs. Instead of being confined in a small space, ADT residents have more freedom of movement, at least within a predetermined radius. Despite their greater mobility, they still face limitations, marginalization, and rights deprivation. Their placement in an ATD is still driven by containment and social segregation, thereby preventing any form of temporary or permanent integration. Again and again, the Indonesian government has made it clear that the only durable solutions for asylum seekers and refugees coming to Indonesia are repatriation and resettlement, but not local integration. Thus the Indonesian ministry keeps urging the UNHCR to "act faster" on registering and assessing asylum claims, and finding a permanent solution for recognized refugees anywhere else but Indonesia. ${ }^{71}$ By stressing that Indonesia with its population of more than 250 million is still a poor country that can hardly provide sufficient services for its citizens, subsequent Indonesian governments have rejected responsibility to provide permanent protection for asylum seekers and refugees..$^{72}$ Indonesian refugee rights activists, however, object to this argument. In their view the root problem "is not that Indonesia is a poor country," but rather insufficient awareness, lack of political will, and absence of a proper legal framework. ${ }^{73}$ Nonetheless, the establishment of ATD serves the Indonesian government well, not only because it is even cheaper than the immigration detention system, but its more humane setting also saves the government from criticism for maltreatment of detained asylum seekers and refugees. On the basis of visits of several ATD, however, I have encountered deficiencies, such as absence of basic rights, segregation, and lack of choice for self-determined living, that support the notion of carceral mobility, which I had conceptualized earlier as an alternative form of containment, albeit one with greater physical mobility. 
First, although asylum seekers and refugees in ATD in Indonesia are subject to Indonesian law, they are often prevented from exercising their rights. They face insufficient legal protection, as they tend to avoid state authorities, whom they view as predatory. The absence of basic rights, such as education and work, mean that ATD are not yet a panacea for asylum seekers and refugees in Indonesia. As I have shown for the ATD in Aceh and Makassar, most asylum seeker and refugee children are still not allowed to attend local schools and must rely on the rudimentary and sporadic provision of language and literacy classes offered by IOM or NGOS. Moreover, the prohibition of work and the resulting inability to earn money legally controls not only the socioeconomic mobility of asylum seekers and refugees in ATD, but in fact prevents any form of integration within the wider Indonesian society. Both in Aceh and Makassar local governments have experimented with forms of unremunerated work. In Makassar the women from the ATD were asked to sew traditional costumes and bags to exhibit at a local handicraft fair, but they were barred from selling their products. ${ }^{74}$ In Aceh, stock-breeding is currently tested. Although central government officials argue vehemently against proper working rights and thus temporary integration of refugees in Indonesia, such pragmatic employment options appear more practicable than the isolation of asylum seekers and refugees in ATD, where they depend on aid and services provided by IOM and NGOS.

Second, similar to IDCs, ATD support their residents' social isolation and segregation from the surrounding Indonesian communities, as they tend to be located on the outskirts of cities, in separate kampungs, or, if located more centrally, they are walled off. 75 Minimal public attention is supposed to stem xenophobic backlashes. Negative public perceptions and repeated public complaints about ATD in general or allegations of the cultural or sexual misbehaviour of individual asylum seekers and refugees have in some cases resulted in the permanent closure of shelters. As already noted, the provision of aid and services engenders negative perception and social jealousy among local Indonesian populations, as summarized by one Acehnese: "They [the Rohingya] want eat, just eat ...! They want sleep, just sleep ...! Everything is prepared for them ...! No need to work ...!"76 However, it seems that the segregation from public spheres is not only a strategy chosen by the IOM and the local authorities to decrease tensions, but it is partly also self-imposed by asylum seekers and refugees for safety. Particularly the events in Aceh showed the inability or unwillingness of Indonesian guards to protect vulnerable asylum seekers and refugees from (sexual) violence and theft. An Afghan refugee in Makassar who had been beaten up summarized the problem: "I can't do anything about this [Indonesians beating up foreigners] because I enter[ed] Indonesia illegally. And when they beat us up, I can't fight back."77 Any involvement in brawls and other disturbances increases the risk of being returned to an IDC. Thus, many other precautionary steps adopted by ATD residents attest to their self-imposed invisibility, such as not practising their religion openly. As the snapshot from Makassar showed, Shia are particularly aware of the antiShia sentiment and attacks. ${ }^{78}$ From this perspective, living in an Indonesian ATD bears a resemblance to what Brendese described as "vida encerrada,"79 not so much as in the necessary clandestine nature of their existence as migrants who crossed the border illegally, but rather in the restrictions they impose upon themselves to avoid being conspicuous among potentially hostile hosts.

Third, while ATD residents enjoy greater physical mobility than their IDC-imprisoned counterparts, they too are subject to restricted freedom of movement. Any violation of the "declaration of compliance," a document every released asylum seeker and refugee must sign, risks return to an IDC. ATD residents are closely monitored by immigration authorities, to whom they must report frequently to continue receiving aid and services. Reporting obligations require them to stay within a certain radius of their assigned location. Although many Rohingya in Aceh left clandestinely, only a few absconded from the ATD in Makassar. ${ }^{80}$ Without money they cannot go anywhere else in Indonesia or leave Indonesia by irregular means, so their (onward) mobility is circumvented tremendously. These limitations and dependencies make their mobility carceral. In fact, it appears that the newly gained freedoms of living in ATD are, in fact, paradoxical: in IDCs, entry is open to anybody who is arrested or surrenders, but the exit is blocked; in ATD it is the other way round, with the entry blocked to those who have not been referred to the ATD by immigration authorities, but the exit open, at least in theory. Those who leave the ATD have nowhere to go within Indonesia and risk destitution, exploitation, and rearrest and re-detention. Their carceral mobility means that although they are no longer incarcerated, they are stuck in a carceral archipelago. ${ }^{81}$

\section{Conclusion: Deterrence and Containment Continue}

This article has questioned whether ATD in Indonesia offer a proper alternative to detention or whether they are simply arrangements for alternative detention in the sense of containment. During fieldwork and interviews with current ATD residents in two ATD sites, I was interested in the lived experiences of asylum seekers and refugees, including aspects of their freedom; physical, social, and economic mobility; mechanisms for their care and aid provision; political, cultural, and religious rights to lead an active and 
self-determined life; and matters of personal safety and well-being.

The snapshots from the field have indicated that as a result of administrative discretion, inconsistency, general vulnerability, indignity, and lack of control over life, ATD in Indonesia render residents insecure and immobile and deny them rights. Post-detention life in an ATD does not alleviate the uncertainty of waiting, and the stress of a potential return to an IDC should not be underestimated. As in IDCS, asylum seekers and refugees in ATD are deprived of basic rights, such as access to education and work, and their freedom of religion is limited, especially for Shia. Whereas asylum seekers in Europe are immobilized by being labelled as criminal border crossers and are, therefore, deprived of political rights during their journeys, ${ }^{82}$ asylum seekers and refugees in Indonesia are more likely to become contained through their dependency on aid and services.

Although ATD are generally perceived as benign places, in fact the embodiment of more humane migration management, which makes them an alternative to IDC, they are not a comprehensive alternative to the more holistic detention systems in place in Indonesia that seek to deter self-organized onward movements. The more humane accommodation in ATD does not annul the overall "containment"-as resettlement options from Indonesia have been decreased and self-organized onward migration to Australia has been ruled out-nor "stuckedness," which persists as there is no avenue for local integration. The indefinite nature of their stasis in transit in Indonesia, whether in ATDS or ATD, is perceived by these transiting asylum seekers as punitive and becomes in itself a powerful deterrent for potential future arrivals. ${ }^{83}$ The carceral mobility inherent in ATD is not only an unintended impact of poor and inadequate asylum regulation in Indonesia, but also another means of deterrence, which prevents or limits unwanted cross-border movement into Australia. With these three deficiencies-absence of basic rights, segregation, and lack of proper choices for self-determined living-ATD in Indonesia remain an effective tool of current containment and deterrence policies.

\section{Notes}

1 Under Indonesian law (no. 6/2011), foreigners without valid passports and visa, including asylum seekers and refugees, can be placed in immigration detention to prevent unauthorized entry, stay, or exit and to effect removal for rejected asylum seekers. Although the law does not name asylum seekers and refugees explicitly, I choose this terminology here in this article over the more general term migrant, not least as the population concerned has already registered, or is in the process of registering their claims for international protection with the UNHCR in Jakarta.
2 Human Rights Watch, Barely Surviving: Detention, Abuse and Neglect of Migrant Children in Indonesia (New York: HRW, 2013), 82-5.

3 Amy Nethery, Brynna Rafferty-Brown, and Savitri Taylor, "Exporting Detention: Australian-Funded Immigration Detention in Indonesia," Journal of Refugee Studies 26 (2013): 88-109; Amy Nethery and Carly Gordon, "Australia-Indonesia Cooperation on Asylum-Seekers: A Case of 'Incentivised Policy Transfer," Australian Journal of International Affairs 68 (2014): 177-93.

4 UNHCR Indonesia, "National Action Plan, Indonesia," November 2015, http://www.unhcr.org/5666a2ea9.pdf.

5 Although the UNHCR strategy is a global initiative, Indonesia was one of twelve initial countries for which a national action plan was prepared for the adoption of the guiding objectives of the Beyond Detention agenda; the others were Canada, Hungary, Israel, Lithuania, Malaysia, Malta, Mexico, Thailand, the UK, the us, and Zambia. See Alice Edwards, "From Routine to Exceptional: Introduction to UNHCR's Global Strategy-Beyond Detention 2014-2019: Supporting Governments to End the Detention of AsylumSeekers," Refugee Survey Quarterly 35 (2016): 128-33.

6 Cathryn Costello and Esra Kaytaz, Building Empirical Research into Alternatives to Detention: Perceptions of Asylum-Seekers and Refugees in Toronto and Geneva, Legal and Protection Policy Research Series (Geneva: UNHCR Division of International Protection, 2013); Alice Szczepanikova, "Between Control and Assistance: The Problem of European Accommodation Centres for Asylum Seekers," International Migration 51, no. 4 (2013): 130-43.

7 Alexander Nicholas, "Protecting Refugees: Alternatives to a Policy of Mandatory Detention," Australian Journal of Human Rights 8 (2002): 69-81; Alice Edwards, Back to Basics: The Right to Liberty and Security of Person and "Alternatives to Detention" of Refugees, Asylum-Seekers, Stateless Persons and Other Migrants (Geneva: UNHCR Division of International Protection, 2011); Edwards, "From Routine to Exceptional"; Robin Sampson and Glen Mitchell, "Global Trends in Immigration Detention and Alternatives to Detention: Practical, Political and Symbolic Rationales," Journal on Migration and Human Security 1 (2013): 97-121; Catherine Marshall, Suma Pillai, and Louise Stack, "Community Detention in Australia: A More Humane Way Forward," Forced Migration Review 44 (2013): 55-7; Costello and Kaytaz, Building Empirical Research.

8 Alice Bloomfield, "Alternatives to Detention at a Crossroads: Humanisation or Criminalisation?" Refugee Survey Quarterly 35 (2016): 31.

9 Robyn Sampson, Vivienne Chew, Grant Mitchell, and Lucy Bowring, There Are Alternatives: A Handbook for Preventing Unnecessary Immigration Detention, rev. ed. (Melbourne: International Detention Coalition, 2015), vi.

10 Bloomfield, "Alternatives to Detention," 29-46; Julia Morris, "Power, Capital, and Immigration Detention Rights: Making Networked Markets in Global Detention Governance 
at UNHCR," Global Networks early view (2016); Philippe de Bruycker and Evangelia Tsourdi, "The Challenge of Asylum Detention to Refugee Protection," Refugee Survey Quarterly 35 (2016): 1-6. While potential destination countries in the Global North have for many years opted to detain asylum seekers and undocumented migrants in IDCs as a means of curtailing unwanted flows-see, for example, Alexander Betts, Global Migration Governance (Oxford: Oxford University Press, 2011); and Dominique Moran, Nick Gill, and Deirdre Conlon, eds., Carceral Spaces: Mobility and Agency in Imprisonment and Migrant Detention (Aldershot: Ashgate, 2013)-countries of the Global South (e.g., Turkey, Jordan, Kenya), which face much larger populations of asylum seekers, refugees, and undocumented migrants lacked the financial means to establish and operate effective IDC systems. Rather, they tolerated asylum seekers and refugees organizing their own living in urban settings or allowed aid organizations to manage large camps.

11 For example, Moran, Gill and Conlon, Carceral Spaces; Rich Furman, Douglas Epps, and Greg Lamphear, eds., Detaining the Immigrant Other: Global and Transnational Issues (New York: Oxford University Press, 2016); Amy Nethery and Stephanie Silverman, eds., Immigration Detention: The Migration of a Policy and Its Human Impact (London: Routledge, 2015); Dominique Moran, Carceral Geography: Spaces and Practices of Incarceration (Aldershot: Ashgate, 2015).

12 Jessie Taylor, Behind Australian Doors: Examining the Conditions of Detention of Asylum Seekers in Indonesia, Asylum Seekers in Indonesia: Project, Findings \& Recommendations, 2009,http://www.safecom.org.au/pdfs/behindaustralian-doors-examining-the-conditions.pdf; Nethery, Rafferty-Brown and Taylor, "Exporting Detention"; Amy Nethery, Brynna Rafferty-Brown, and Savitri Taylor, "At the Discretion of Management: Immigration Detention in Indonesia," in Nethery and Silverman, Immigration Detention, 114-24; Antje Missbach, "Detaining Asylum Seekers and Refugees in Indonesia," in Furman, Epps, and Lamphear, Detaining the Immigrant Other, 95-104.

13 Based on IOM statistics, the ratio between the people detained in IDCs and those in ATD started shifting in early 2012. Whereas until 2011, the majority of asylum seekers and refugees under IOM care used to be detained, the number of those in ATD increased in relative and absolute numbers.

14 Dominique Moran, Laura Piacentini, and Judith Pallot, "Disciplined Mobility and Carceral Geography: Prisoner Transport in Russia," Transactions of the Institute of British Geographers 37 (2012): 446-60.

15 Ibid., 446, 447.

16 Savitri Taylor and Brynna Rafferty-Brown, "Waiting for Life to Begin: The Plight of Asylum Seekers Caught by Australia's Indonesia Solution," International Journal of Refugee Law 22, no. 4 (2010): 558-92; Ishan Ashutosh and Alison Mountz, "Migration Management for the Benefit of Whom? Interrogating the Work of the International Organization for Migration," Citizenship Studies 15 (2011): 21-38; Nethery, Rafferty-Brown, and Taylor, "Exporting Detention"; Nethery, Rafferty-Brown, and Taylor, "At the Discretion of Management"; Antje Missbach, Troubled Transit: Asylum Seekers Stuck in Indonesia (Singapore: ISEAS, 2015); Anne McNevin, Antje Missbach, and Deddy Mulyana, "The Rationalities of Migration Management: Control and Subversion in an Indonesia-Based CounterSmuggling Campaign," International Political Sociology 10, no. 3 (2016): 223-40.

17 While Jakarta is the obvious choice for many new asylum seekers, because of the UNHCR's presence there, accommodation and transportation in this megacity (covering 740.3 $\mathrm{km}^{2}$ ) is relatively expensive. Nearby Puncak, a cluster of smaller villages about $60 \mathrm{~km}$ from Jakarta, offers cheaper living and a more comfortable, cooler climate (see Missbach, Troubled Transit).

18 See IOM, Irregular Migrants Statistics, December 2011, March 2012, and January 2015.

19 UNHCR, Monthly Update; IOM, Migrant Statistics under the IOM Indonesia Programme as at 30 April 2016.

20 komnas ham, Temuan Hasil Pemantauan коmnas ham: Pemantauan Situasi di 7 Rumah Detensi Imigrasi dan 1 Kantor Imigrasi (Jakarta, 2015).

21 Interview with Steve Hamilton, deputy head of Mission, IOM Indonesia, 29 April 2015, Jakarta.

22 "Gubernur Sulsel Raih Penghargaan dari Kemenkumham," Antara, 16 February 2016, http:// makassar.antaranews.com/berita/7210o/gubernursulsel-raih-penghargaan-dari-kemenkumham.

23 Missbach, Troubled Transit.

24 Initially the Indonesian navy prevented one boat from landing and, after providing some fuel and food, turned it away from Indonesian waters. However, against official orders, Acehnese fishermen rescued the Rohingya, took them ashore, and provided the emaciated passengers, many of whom had been at sea for months, with food and clothing. Amnesty International, Deadly Journeys: The Refugee and Trafficking Crisis in Southeast Asia (London: AI, 2015).

25 Yayasan Geutanyoe, Hidup Dalam Penantian: Setahun Pengungsi Rohingya di Aceh (Langsa: Yayasan Geutanyoe, 2016).

26 Ministerial Meeting on Irregular Movement of People in Southeast Asia, "Joint Statement," Governments of Indonesia, Malaysia, and Thailand, 20 May 2015.

27 Yayasan Geutanyoe, Hidup Dalam Penantian, 12.

28 Krisna Wicaksono and Mitra Angelia: "Ini Alasan RI Belum Ikut Konvensi рвв Soal Pengungsi," Viva, 22 May 2015, http://dunia.news.viva.co.id/news/read/629261-inialasan-ri-belum-ikut-konvensi-pbb-soal-pengungsi.

29 Missbach, Troubled Transit.

30 At the end of 2014, there were 270,621 asylum seekers, refugees. and stateless people in Malaysia and 644,761 in Thailand. See UNHCR, World at War: Global Trends-Forced 
Displacement in 2014 (Geneva: UNHCR, 2015), http://www. unhcr.org/statistics/country/556725e69/unhcr-globaltrends-2014.html.

31 UNHCR, Monthly Update, Jakarta, March 2016.

32 Yurod Saleh, "Permasalahan dan Solusi Penempatan dan Pengawasan Imigran Illegal," PowerPoint presentation, focus group discussion, Penempatan dan Pengawasan Imigran Illegal, Jakarta, 26 November 2015.

33 Antje Missbach, "From Darfur to Cipayung: Refugees Are Left Stranded," Conversation, 6 April 2014, https://theconversation.com/from-darfur-to-cipayung-refugees-are-leftstranded-25034; UNHCR Indonesia, National Action Plan.

34 UNHCR, Monthly Update.

35 Janet Phillips, Boat Arrivals and Boat "Turnbacks" in Australia since 1976: A Quick Guide to the Statistics (Canberra: Parliamentary Library, 2015), http://www.aph.gov .au/About_Parliament/Parliamentary_Departments/ Parliamentary_Library/pubs/rp/rp1617/Quick_Guides/ BoatTurnbacks.

36 From an empirical view, it is hard to provide exact figures for the average time in waiting experienced by asylum seekers and refugees in Indonesia. The data collected by the Iом, for example, differentiates only between less than one year, more than two to three years, and more than four years. From encounters during fieldwork, some refugees, however, have been living in Indonesia closer to ten years.

37 "Rumah Detensi Imigrasi Dianggap Tidak Perlu Ditambah," 7 March 2011, http://pencarisuakaindonesia.blogspot. com.au/2011/o3/rumah-detensi-imigrasi-dianggap-tidak .html.

38 Ken Ward, Condemned to Crisis? (Sydney: Lowy Institute Papers, 2015).

39 Ophelia Field and Alice Edwards, Alternatives to Detention of Asylum Seekers and Refugees, Legal and Protection Policy Research Series (Geneva: UNHCR Division of International Protection, 2006).

40 гом Indonesia, Alternatives to Detention 4 (September 2014): 4, https://www.iom.int/files/live/sites/iom/files/ Country/docs/IOM-Indonesia_Alternatives-to-detentionSeptember-2014.pdf.

41 Interview with young Afghani refugee, who had his bags searched by Indonesians officials, was kicked by them, and had to pay Us $\$ 180$ to be placed in an ATD eventually (10 May 2015, Makassar).

42 The declaration supplied to its signatories in English reads:

1. Refugees should stay within specific area designated by Directorate General of Immigration unless given written permission to transfer or temporarily leave for reasons related to the processing of their resettlement.

2. Refugees are not allowed to be in an airport or seaport unless accompanied by Immigration officials.

3. Refugees are not allowed to have guests stay inside the accommodation provided.

4. Refugees must fully comply with Indonesian Laws, including regulations related to employment, business activities, use of motor vehicles and cooperative behaviour in the neighbourhood.

5. Refugees must report to Immigration every 2 weeks for purposes of registering their presence.

43 Szczepanikova, "Between Control and Assistance," 138.

44 The English version stated:

Asylum seekers and refugees are not allowed to drive any vehicles.

Asylum seekers and refugees are not allowed to receive guests inside the accommodation room and commit sexual misconduct anywhere.

Asylum seekers and refugees are not allowed to consume any substance (alcohol and or narcotics), whether legal or not, that may lead to social unrest or conflict within the accommodation and community at large, gambling and going to the night club.

Asylum seekers and refugees have to be in accommodation the latest at 10:00 PM.

Asylum seekers and refugees are not allowed to make a scene, fighting and or do violence anywhere.

Asylum seekers and refugees are not allowed to leave Makassar city without the permission of Immigration Office Makassar.

Asylum seekers and refugees are not allowed to be involved in political activities or other mass organisation.

Any violation of the above, Asylum seekers and refugees will be subject to strict sanctions [bold in original].

45 In July 2014, 20 refugees, all of them from Myanmar, escaped from the community shelters in Makassar. See Iom, Irregular Migrants Statistics, July 2014. The ethnic dimension of escaping is obvious, as it is much easier for Myanmarese than for Afghans to blend in among the Indonesian population.

46 "Makassar Hentikan Penerimaan Imigran Pencari Suaka," Kompas, 16 May 2016, http://regional.kompas. $\mathrm{com} / \mathrm{read} / 2016 / 05 / 16 / 10004021 /$ Makassar.Hentikan. Penerimaan.Imigran.Pencari.Suaka.

47 One of the worst attacks on Shia asylum seekers in an ATD was in Yogyakarta in October 2015. Guards at the centre could not protect the asylum seekers adequately from the mob and, after a night of fear, they were evacuated and taken to the IDC in Semarang, which was deemed safer. See "Anti-Shiite Mob Storms Yogyakarta Shelter for Asylum Seekers," Jakarta Globe, 20 October 2015. In Stabat, near Medan, a shelter for unaccompanied minors had to be closed after villagers' allegations of Shia proselytization.

48 "Pemkot Makassar Gelar Sosialisasi Terkait Keberadaan Imigran," Antara, 2 April 2015, http://www.antarasulsel .com/berita/63675/pemkot-makassar-gelar-sosialisasiterkait-keberadaan-imigran.

49 Informal chats with asylum seekers and refugees and villagers, 10 May 2015, Makassar.

50 Interview with Kaharuddin Bakti, Subdistrict head, 11 May 2015, Makassar.

51 Interview with Afghan refugee, 10 May 2015, Makassar. 
52 Follow-up sms message from an asylum seeker I had interviewed during the May 2015 visit.

53 IOM Indonesia, Alternatives to Detention, 4.

54 "Potret Pengungsi Asing di Kota Angin Mamiri," webpage of the Indonesian vice president (who hails from Makassar), 16 November 2015, http://www.wapresri.go.id/ potret-pengungsi-asing-di-kota-angin-mamiri/.

55 Iом, Migrant Statistics under the Iом Indonesia Programme as at 30 April 2016.

56 Iом Thailand, Bay of Bengal and Andaman Sea Crisis (Bangkok, 2015), https://www.iom.int/sites/default/files/ situation_reports/file/IOM-Andaman-Sea-Crisis-SituationReport-September-2015-Highlights.pdf.

57 Jonathan Vit, "Rohingya Refugees Vanish from Indonesia," IRIN, 14 December 2015, http://www.irinnews .org/report/102293/rohingya-refugees-vanish-indonesia; Yayasan Geutanyoe, Hidup Dalam Penantian.

58 "Pengungsi Rohingya Direlokasi," Tribunnews, 20 March 2016, http://aceh.tribunnews.com/2016/03/20/pengungsirohingya-direlokasi. The local government in Langsa offered the new camp for other local governments in Aceh to use, but the offer was not taken up, presumably because the presence of the Rohingya had attracted substantial NGO services, so that the other local governments were uneasy to let go of "their" refugees, as that would have limited the spillover effect from the NGOs' services. Many NGOS, however, are on their way out of the camps, as fundraising had declined.

59 IOM Thailand, Bay of Bengal and Andaman Sea Crisis.

60 For example, with the help of volunteer workers and donations from all over Indonesia, Aksi Cepat Tanggap (action for swift response, АСT) erected the barracks for the camp in Blang Adoe.

61 "Topang keluarga, pengungsi Rohingya berdagang keliling," ввС Indonesia, 20 May 2016, http://www.bbc.com/ indonesia/berita_indonesia/2016/05/160517_indonesia_ rohingya_jualan.

62 See presentation given by Suriyatno, deputy head of the task force for the handling of refugees in Langsa, at South East Asia Conference on Rohingya: "Humanitarian Diplomacy as a Possible Solution," Bogor, 18-19 May 2016.

63 Amiruddin Abdullah Reubee, "18 Pasangan Pengungsi Rohingya Minta Menikah,” MetroTV, 4 August 2015, http://news.metrotvnews.com/read/2015/08/04/418232/18pasangan-pengungsi-rohingya-minta-menikah; "Warga Rohingya Ikut Nikah Massal di Aceh," Kompas, 30 August 2015, http://megapolitan.kompas.com/ $\mathrm{read} / 2015 / 08 / 30 / 16305311 /$ Warga. Rohingya.Ikut.Nikah .Massal.di.Aceh.

64 Authors' observation in Blang Adoe, 18 November 2015.

65 Amnesty International, Deadly Journeys.

66 The rape allegations could not be backed up by medical checks. The police investigation was put on hold when the four women disappeared from Aceh (authors' interview with Teuku Mansur, head of social affairs, 17 November 2015, Lhokseumawe).
67 Amnesty International, Deadly Journeys.

68 коmnas Ham, Laporan Pemenuhan Hak Asasi Manusia Terhadap Penanganan Pengungsi Rohingya di Indonesia (Jakarta, 2016).

69 For example, the Indonesian foundation Society for Health Education and Environment and Peace (Sheep) engaged in programs to enhance mutual understanding between Rohingya and Acehnese villagers. Presentation by Yulia Rina Wijaya, "Building Peaceful Coexistence between Rohingya Refugees and Buffer Communities in Langsa City and East Aceh," South East Asia Conference, "Rohingya: Humanitarian Diplomacy as a Possible Solution," Bogor, 18-19 May 2016.

70 Asrul, "Bocah Rohingya di Langsa Mulai Bersekolah," Aceh Journal National Network, 29 March 2016, http://www.ajnn. net/news/bocah-rohingya-di-langsa-mulai-bersekolah/ index.html.

71 Indonesian Foreign Ministry, "Indonesia Minta UNHCR Percepat Penanganan Pengungsi dan Pencari Suaka," 22 March 2016, http://kemlu.go.id/id/berita/Pages/IndonesiaMinta-UnHCR-untuk-Percepat-Penanganan-Pengungsidan-Pencari-Suaka.aspx.

72 Interview with Ibrahim Nur, deputy director of humanitarian affairs at the Ministry of Foreign Affairs, 4 April 2012, Jakarta.

73 Presentation by Febi Yonesta, co-founder of the Indonesian refugee advocacy organization Suaka, "Advocating Rohingya Refugee Rights in Indonesia," South East Asia Conference, "Rohingya: Humanitarian Diplomacy as a Possible Solution," Bogor, 18-19 May 2016.

74 "Sosialisasi Keberadaan Imigran," Antara, 2 April 2015, http://www.antaranews.com/foto/81675/sosialisasikeberadaan-imigran.

75 See also Raimund Pehm, "Provisorien als Dauereinrichtung: Zur Wahl Organisierter Unterkünfte für Asylsuchende durch die Öffentliche Hand," Österreichische Zeitschrift für Soziologie 31 (2006): 66-74.

76 Statement by an Acehnese man who participated in a radio program organized by a community councillor, presented by Yulia Rina Wijaya, "Building Peaceful Coexistence between Rohingya Refugees and Buffer Communities."

77 Interview with Afghan refugee, 10 May 2015, Makassar.

78 Chiara Formichi, "Violence, Sectarianism, and the Politics of Religion: Articulations of Anti-Shía Discourses in Indonesia," Indonesia 98 (2014): 1-28.

79 P.J. Brendese, "Double Crossed by the Crossing: On the Spacio-Temporal Borders of Immigration," Contemporary Political Theory 12 (2013): 230-40.

80 IOM, Migrant Statistics under the IOM Indonesia Programme as at 31 January 2016.

81 The term carceral archipelago was coined by Michel Foucault, in Surveiller et Punir (Paris: Gallimard, 1975), when he was writing about the prison and surveillance systems and about technologies controlling and disciplining members of modern societies. Although Foucault did not have 
Indonesia in mind, the metaphor of prison islands seems a good fit here, given Indonesia's geography.

82 Annastiina Kallius, Daniel Monterescu, and Prem Kumar Rajaram, "Immobilising Mobility: Border Ethnography, Illiberal Democracy, and the Politics of the 'Refugee Crisis' in Hungary," American Ethnologist 43 (2016): 3.

83 Anne McNevin and Antje Missbach, "Luxury Limbo: Temporal Techniques of Border Control and the Humani- tarianisation of Waiting," International Journal of Migration and Border Studies, forthcoming.

Antje Missbach is a senior research fellow at the School of Social Sciences at Monash University in Melbourne. The author may be contacted at antje.missbach@monash.edu. 